\title{
Foreign esophageal body - diagnostic dillemas
}

\author{
Corp străin esofagian - dileme diagnostice
}

\begin{tabular}{c}
\hline Adina Zamfir-Chiru-Anton', Dan-Cristian Gheorghe2,3 \\
'Spitalul Clinic de Urgenţă pentru Copii „Grigore Alexandrescu“, Bucureşti, România \\
2Spitalul Clinic de Urgenţă pentru Copii „M.S. Curie“, Bucureşti, România \\
3Universitatea de Medicină şi Farmacie "Carol Davila“, Bucureşti, România \\
\hline
\end{tabular}

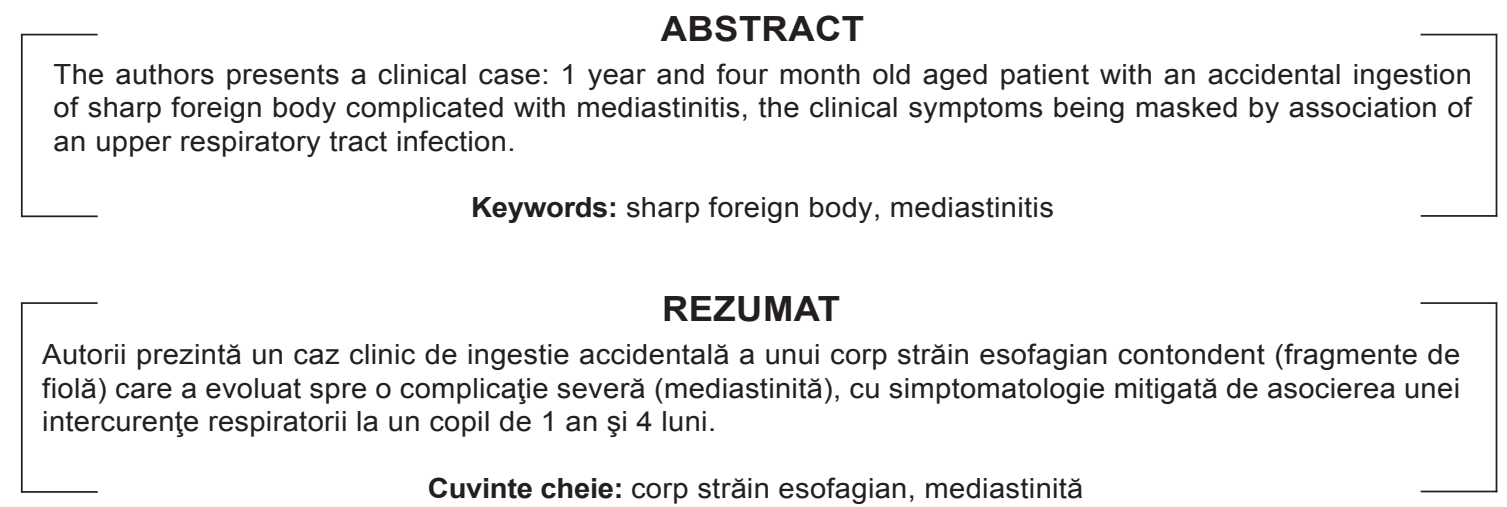

\section{INTRODUCERE}

Corpii străini esofagieni sunt grevați de apariția mai multor complicații posibile: perforații, abcese retrofaringiene, mediastinite, fistule traheo-esofagiene (1). Apariția acestor complicații poate fi marcată de o rată mare de letalitate (peste $50 \%$ în cazul mediastinitelor) (2).

S-a demonstrat că durata mare de impactare a corpului străin influențează semnificativ rata de apariție a complicațiilor $(1,3)$.

Apariția complicațiilor de tip perforativ sau imposibilitatea extragerii endoscopice indică extragerea prin esofagotomie/faringotomie, atitudine dictată de topografia impactării corpului străin (4). $10 \%$ dintre cazuri au necesitat extragerea chirurgicală, după unii autori (4).

Numeroase cazuri citate în literatura de specialitate confirmă dificultatea extracției dacă durata de impactare a corpului străin depăşeşte 24 de ore (5).

\section{PREZENTARE DE CAZ}

Copil în vârstă de 1 an şi 4 luni, cunoscut cu ingestie accidentală a unor fragmente de sticlă (spargerea unei fiole în dinți, urmată de deglutiție, profitând de lipsa de atenție a mamei), se internează prin tranfer dintr-un alt spital pentru investigații şi atitudine teraputică. Precizăm că de la momentul ingestiei pâna la momentul investigației endoscopice au trecut aproximativ 50 ore, timp în care pacientul a primit alimente solide, dar şi lapte matern.

În momentul prezentării la camera de gardă, copilul avea stare generală bună, era conştient, cooperant, afebril, fără elemente clinice care să sugereze prezența unui corp străin (făra sialoree, fără disfagie sau odinofagie). Avea în schimb o tuse productivă care dura de aproximativ o săptămână şi pentru care era în tratament cu antibiotic, antiinflamator, antitusiv, mucolitic, după o schemă de tratament stabilită de către medicul său pediatru. 
Aspectul clinic din momentul prezentării, prin tusea iritativă (care putea sau nu să fie corelată cu o eventuală aspirație), precum şi anamneza dificilă (mama cu nivel intelectual precar) au ridicat suspiciunea unei eventuale aspirații a fragmentelor de sticlă şi au impus explorarea suplimentară a arborelui traheobronşic prin bronhoscopie rigidă.

S-a decis practicarea intervenției endoscopice sub anestezie generală.

Examenul bronhoscopic a evidențiat secreții mucoase şi mucopurulente în cantitate mare, care s-au aspirat, dar fără a decela un corp străin sau alte elemente patologice în teritoriile examinate.

Esofagoscopia rigidă a evidențiat o formațiune granulomatoasă cu bază mare de implantare la nivelul regiunii posterolaterale de partea dreaptă a esofagului toracic, dar fără alte leziuni.

Postinterventional, copilul a primit tratament perfuzabil cu antibiotic cu spectru larg, antiinflamator steroidian, inhibitor de pompă de protoni pentru protecția gastrică. Pentru câteva ore, copilul a prezentat o evoluție favorabilă, după care s-a decompensat brusc, cu stare generală mediocră, somnolență, febră înaltă $\left(39,8^{\circ} \mathrm{C}\right)$, dispnee şi polipnee (semne de insuficiență respiratorie acută).

Analizele recoltate în urgență, mult diferite de cele din momenul internării (care erau cvasinormale), au fost în concordanță cu starea generală alterată a copilului: leucocitoză marcată cu neutrofilie, probe inflamatorii mult crescute, proba ASTRUP care atesta decompensarea respiratorie.

S-a solicitat consult pediatric, care a ridicat suspiciunea unei meningite, dar examenul neurologic a infirma prezența semnelor de iritaţie meningeală.

S-a efectuat cu dificultate o radiografie pulmonară, la care s-au evidențiat modificări de partea hemitoracelui drept, cu lărgirea mediastinului, ridicând suspiciunea unei afectări mediastinale (mediastin lărgit spre dreapta şi diminuarea transparenței pulmonare la nivelul hemitoracelui drept prin revărsat pleural față de examenul precedent). S-a decis practicarea în urgenţă a computerului tomograf toraco-abdominal.

Protocolul examinării imagistice prin computer tomograf a demonstrat (Figurile 1-3): pneumomediastin şi acumulări neomogene cu densități fluide şi parafluide mai marcat la nivelul jumătății superioare a mediastinului posterior şi mijlociu ce comunică la acest nivel cu cavitatea pleurală dreaptă; revărsat pleural neomogen, cu grosimea de $10 \mathrm{~mm}$ posterior, ce conține câteva bule aerice; mic pneumotorax anterior drept; densificări alveolo-interstițiale la nivelul segmentelor apical al lobului inferior drept şi posterior al lobului superior drept; fără revărsat pericardic; cord fără modificări de volum; fără modificări de structură osoasă la nivelul segmentelor scanate. În concluzie: aspectul a fost sugestiv pentru mediastinită acută prin perforație esofagiană care comunica cu cavitatea pleurală dreaptă.

S-a trasferat de urgență copilul pe secția de terapie intensivă, unde a fost monitorizat, pus în repaus digestiv prin sondă nazogastrică şi s-a stabilit o schemă de tratament cu antibiotice cu spectru larg care să acopere şi bacteriile anaerobe (meronem, amikacină şi metronidazol), inhibitor de pompă de protoni, antiinflamator nesteroidian.
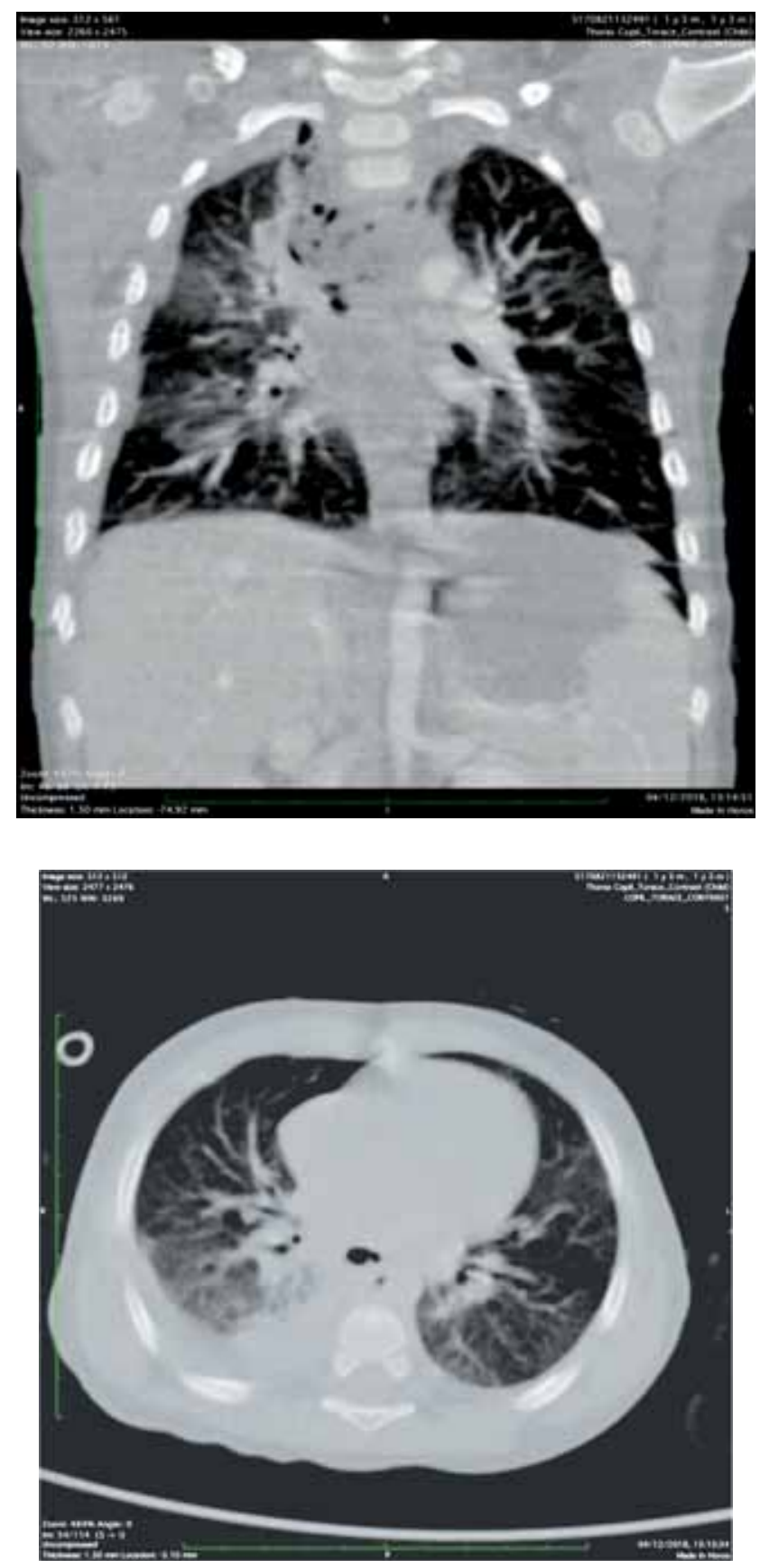

FIGURA 1 şi FIGURA 2. Acumulări neomogene cu densități fluide şi parafluide mai marcat la nivelul jumătății superioare a mediastinului posterior 


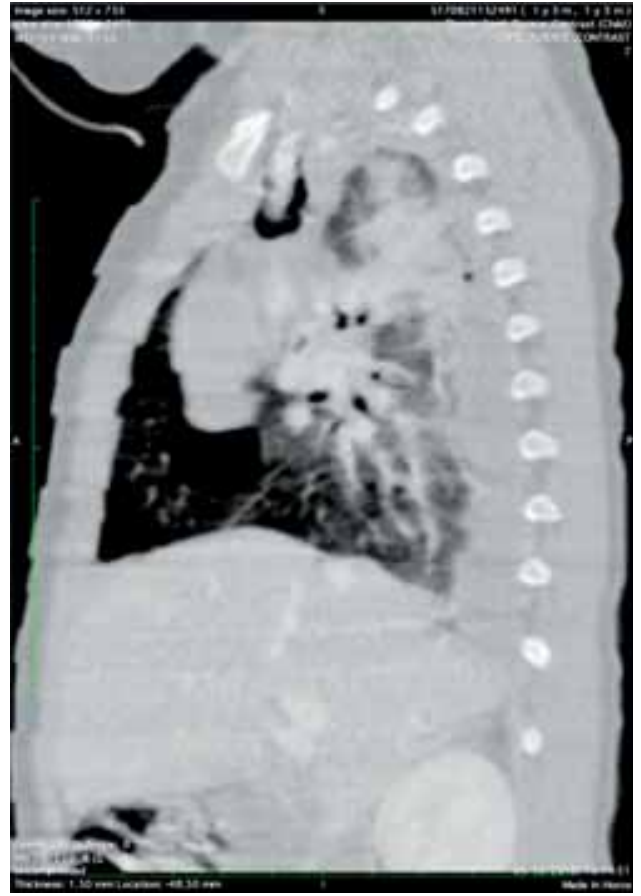

FIGURA 3. Mic pneumotorax anterior drept

În evoluţia din acest moment, am remarcat: clinic, tumefacția regiunii laterocervicale drepte, efort de respirație, creşterea revărsatului pleural - aspect confirmat ecografic prin mărirea lamei de lichid pleural de la $10 \mathrm{~mm}$ la $30 \mathrm{~mm}$.

Consultul chirurgical a impus toracoscopia exploratorie dreaptă. La nivelul cavității pleurale drepte s-a pus în evidență lichid purulent în cantitate mare (s-au trimis probe pentru biochimie, celularitate, culturi şi antibiogramă). Plămânul drept prezenta multiple aderențe pleuropulmonare în special la nivelul lobului superior şi posteromedial. S-a practicat liza aderențelor, s-a evacuat lichid purulent în cantitate mare şi s-a pus în evidență un abces la nivelul mediastinului posterior şi medial, care s-a drenat, concomitent cu decorticarea pleurală şi lavaj. Postoperator, evoluția a fost favorabilă sub protecția antibiotică.

\section{DISCUTुII}

Temporizarea prezentării la spital a fost un factor decisiv în evoluția spre complicația mediastina- lă, coroborată cu continuarea alimentației solide, care a putut duce la impactarea la niveul peretelui esofagian a restului de sticlă.

Evidențierea la examenul endoscopic esofagian a granulomului în regiunea posteromedială dreaptă a fost probabil expresia impactării (inițiale) cu declanşarea secundară a unei reacții inflamatorii care a precedat efracția ciobului în mediastin. Continuarea alimentației orale - atât lichide cât şi solide - a permis pătrunderea în mediastin a unor fragmente din bolul alimentar, determinând constitiurea unui abces care a cloazonat (dovada punților de fibrină). Aceste aspecte (granulomul şi organizarea abcesului prin punți fibrinoase) sunt foarte importante, întrucât exclud varianta unei eventuale perforații acute iatrogene.

Suspiciunea de la început a unei complicații a fost îngreunată de elementele clinice ale afecțiunii respiratorii cu tuse, discretă insuficiență respiratorie, dar şi de administrarea unui tratament ambulator cu antibiotic cu spectru larg, antialgic, antitusiv, tratament care a mascat simptomatologia şi a prevenit decompensarea brutală de la debut.

\section{CONCLUZII}

Corpii străini anfractuoşi reprezintă o urgenţă maximă din cauza potențialului mare de penetrare şi migrare şi trebuie explorați în primele 24 ore (cât mai rapid) pentru a preveni sau depista din timp apariţia complicațiilor.

Considerăm că, în cazul pacienților cu corpi străini trasparenţi, greu de vizualizat atât imagistic, cât şi in vivo, contondenți, cu potențial mare de penetrare şi migrare, determinând distrucții tisulare directe şi indirecte prin pătrunderea la nivelul breşei a fluidelor biologice (suc gastic, intestinal) sau alimentare, trebuie intervenit de la bun început ca având complicații, cu monitorizarea prin internare a pacientului, examinarea imagistică şi urmărirea probelor biologice (formula leucocitară, markeri de inflamație) în dinamică, alături de punerea în repaus a tubului digestiv.

Conflict of interest: none declared Financial support: none declared

4. Orji FT, JO Akpeh, and NE Okolugbo. Management of esophageal foreign bodies: experience in a developing country. World J Surg, 2012. 36(5): p. 1083-8.

5. Chen T et al. Endoscopic management of impacted esophageal foreign bodies. Dis Esophagus, 2013. 26(8): p. 799-806.

\section{BIBLIOGRAFIE}

1. Loh KS et al. Complications of foreign bodies in the esophagus. Otolaryngol Head Neck Surg, 2000. 123(5): p. 613-6.

2. Balasubramaniam SK et al. A review of the current management of impacted foreign bodies in the oesophagus in adults. Eur Arch Otorhinolaryngol, 2008. 265(8): p. 951-6.

3. von Rahden $\mathrm{BH}$ et al. Cervical esophageal perforation with severe mediastinitis due to an impacted dental prosthesis. Dis Esophagus, 2002. 15(4): p. 340-4. 